\title{
Simone de Beauvoir - ständigt aktuell
}

\section{Av Christina Angelfors, universitetslektor i franska}

\author{
Länk till presentation av Christina Angelfors
}

Om två år, 1999, är det femtio år sedan Simone de Beauvoirs epokgörande studie Det andra könet kom ut i Frankrike. Man får nog säga att det är en synnerligen alert och aktuell femtioåring som då kommer att uppmärksammas av feminister och andra världen över. Visserligen har det funnits perioder i den feministiska debatten då Beauvoirs teser ansetts vara "ute", men helt bortglömda har varken författare eller verk någonsin varit under dessa femtio år.

I Sverige har nu Simone de Beauvoir varit i ropet en längre tid. Bara under de senaste åren har vi fått ta del av en mängd artiklar och böcker som behandlar hennes liv, feminism och filosofi. Ett exempel på detta nyväckta intresse är Åsa Mobergs bok Simone och jag (1996). Ett annat är den feministiska tidskriften Bang som under 1996 hade ett stort specialnummer med Simone de Beauvoir som tema. Likaså firades den internationella kvinnodagen i år vid Stockholms universitet med en hel eftermiddag av diskussioner om Simone de Beauvoir. Att man just nu åter riktar uppmärksamheten mot en filosof som Simone de Beauvoir beror kanske på att kulturdebatten är på väg tillbaka mot ett djupare samhällsengagemang och i sådana "nygamla" tankegångar passar Beauvoir med sitt sociala patos utmärkt väl in.

Som ett tecken på tidsandan kan man se det faktum att en nyöversättning av Det andra könet har påbörjats. Läsare som känner till originaltexten har länge påpekat de skandalösa bristerna i den svenska versionen, t ex fattas det hela kapitel, men det är alltså först nu som tiden blivit mogen för en nyutgåva. Den svenska publiken är bara att gratulera som nu äntligen får tillgång till en ocensurerad text! Den som vill forska i tillkomsten av Det andra könet har i Beauvoirs nyligen publicerade brev en ovärderlig källa, särskilt den under våren 97 utkomna volymen Lettres à Nelson Algren.

Beauvoir träffade Nelson Algren under en föreläsningsturné i USA 1947. Det första mötet blev kort, men en intensiv brevväxling följer där Beauvoir bland mycket annat i detalj redogör för den väldiga mängd litteratur som hon ständigt slukar. I breven från 1947 är en av de böcker som hon talar allra varmast om Gunnar Myrdals Ett amerikanskt dilemma, som hon läser i den amerikanska originaltexten. Det är tydligt att hon är djupt imponerad av Myrdals analys av de färgades situation i USA. Myrdal, säger hon, pekar på uppenbara likheter mellan de färgades situationoch den ställning som kvinnor har i samhället, likheter som hon själv redan hade anat. Vid den här tiden hade Beauvoir nämligen arbetat med den bok som skulle bli Det andra könet sedan ett antal år. Men arbetet hade ideligen avbrutits av andra projekt. Nu tycks Myrdals studie fungera både som inspirationskälla och utmaning. Beauvoir säger sig vilja åstadkomma "quelque chose d'aussi important que le Myrdal", dvs något lika bra och betydelsefullt som Myrdals bok. I december 1948 kan Beauvoir meddela sin amerikanske vän att hennes essä kommer att heta Le Deuxième Sexe. Eftersom Algren inte kan franska förklarar hon varför det här är en väldigt lyckad titel. På franska talar man om det "tredje könet", säger Beauvoir, och med det menar man homosexuella män, alltså personer som i det allmänna medvetandet varken är män eller kvinnor. Men det sägs aldrig rent ut, påpekar hon, att på andra plats, mellan de "riktiga" männen och de andra, kommer kvinnorna. Hierarkin mellan könen förblir underförstådd. Ett av Beauvoirs huvudsyften med sin studie är alltså avslöjandet av denna hierarki - av mäns överordning och kvinnors underordning. 
Beauvoirs projekt måste betraktas som synnerligen radikalt i det strikt patriarkaliska samhälle som efterkrigstidens Frankrike utgör med sin hemmafruideologi, sin syn på moderskapet som kvinnans främsta uppgift, sin lagstiftning som förbjuder aborter och t o m användandet av preventivmedel, ett samhälle där kvinnor inte ens har rätt till ett eget bankkonto eller att vara förmyndare för sina barn, ett samhälle som alltså omyndigförklarar kvinnan. Det är viktigt att ha den historiska bakgrunden klar för sig för att förstå vissa av de teser som Beauvoir driver, t ex hennes synnerligen kritiska syn på moderskapet, som många kvinnliga läsare har svårt att förlika sig med. Men Beauvoirs nedvärdering av moderskapet måste ställas i förhållande till den då rådande ideologin, som vill reducera kvinnan till hennes biologiska funktion.

Egentligen är det en omöjlig uppgift som Simone de Beauvoir tar sig an i Det andra könet. För att förklara varför kvinnor under historiens gång alltid haft en underordnad ställning använder hon sig nämligen av två helt skilda och i grunden motstridiga förklaringsmodeller, dels Sartres existentialistiska filosofi, dels en historiefilosofi inspirerad av Marx och Engels. I det första fallet betonas människans fria vilja - ingen kan förtryckas som inte själv vill det -, vilket i förlängningen leder till att kvinnorna ses som "medskyldiga" till sin egen underordning. Denna helt logiska slutsats av Sartres filosofi tonas dock ned hos Beauvoir genom att hon för in en marxistiskt influerad analys som betonar den historiska och sociala situation som individen befinner sig i och som ses som begränsande för människans möjlighet att göra uppror. Detta dubbla perspektiv är en av de grundläggande tvetydigheter som Beauvoirs analys vilar på och som lämnar fältet öppet för debatt och kritiska läsningar.

Den andra stora frågan, som man inte heller kan finna något helt entydigt svar på hos Beauvoir, är den om den "kvinnliga naturen". Beauvoirs mest berömda tes: "Man föds inte till kvinna, man blir det", har även den sitt ursprung i Sartres existentialistiska filosofi. Människan blir den hon gör sig till, menar Sartre. Det finns ingen mänsklig natur och alltså inte heller någon kvinnlig sådan. Tanken på en inneboende "kvinnlighet" avvisas därför bestämt av Beauvoir - på det intellektuella planet bör väl kanske tilläggas. Det är nämligen uppenbart att hon, trots sin föresats att analysera kön som en kulturell konstruktion, hela tiden får kämpa med de essentialistiska tankegångar som såväl hon som samhället och kulturen i stort är genomsyrade av. Kanske är det symptomatiskt att det just är vid analysen av så personliga och känsloladdade områden som sexualitet och moderskap som Beauvoir allra oftast trillar ner i essentialismens fälla och kommer med biologiska förklaringar där hon i konsekvensens namn "borde" ha sökt efter kulturella sådana.

Det är med andra ord lätt för dagens feminister att hitta brister och inkonsekvenser i Simone de Beauvoirs essä. Hennes kritiker gör det gärna, medan hennes anhängare och efterföljare betonar den historiska kontext i vilken verket tillkommit, liksom det faktum att författaren mer eller mindre upptäcker sina idéer i samma takt som hon sätter dem på pränt! Det är inget mindre än sin egen medvetandeprocess som Beauvoir låter oss bli delaktiga av - Det andra könet är helt enkelt ett resultat av hennes lidelsefulla försök att förstå sig själv som kvinna. Paradoxalt nog är det just tvetydigheten och ambivalensen i analysen som gör att boken hela tiden blir föremål för nya tolkningar och upptäckter, vilket också gör författaren själv, Simone de Beauvoir, ständigt aktuell.

\section{(Artikeln publicerad i förkortat skick i Smålandsposten 971024 med rubriken 'Radikalt grepp i efterkrigstidens Frankrike')}

